\title{
Obraz samobójstwa w filmie Sala samobójców w reżyserii Jana Komasy
}

\section{The phenomenon of suicide in a film directed by Jan Komasa Sala samobójców}

\begin{abstract}
ABSTRAKT: Ocena zjawiska samobójstwa jednostki ma niekiedy charakter ambiwalentny. Utrata bliskiej osoby jest niezwykle trudnym doświadczeniem. Samobójstwo z jednej strony może być postrzegane jako strach przed życiem, tchórzostwo czy niechęć do stawienia czoła problemom codziennym, $z$ drugiej zaś interpretowane bywa jako swoisty akt bohaterstwa lub budzący współczucie, wyzwalający empatię. Umiejętność odczytania pewnych poprzedzających ten czyn sygnałów werbalnych i niewerbalnych daje możliwość udzielenia wsparcia osobie, która rozważa popełnienie samobójstwa. W artykule udzielę odpowiedzi na pytanie, czy film Jana Komasy Sala samobójców w odpowiedni sposób przedstawia problematykę zachowań samobójczych wśród adolescentów.
\end{abstract}

SŁOWA KLUCZOWE: młodzież, świat wirtualny, myśli samobójcze, samobójstwo, traumatyczne wydarzenie

ABSTRACT: The assessment of the phenomenon of an individual's suicide is sometimes ambivalent. Losing a loved one is an extremely difficult experience. On the one hand, it can be perceived as fear of life, cowardice or reluctance to face everyday problems, on the other hand, it can be interpreted as a specific act of heroism or compassion, triggering empathy. Being able to read certain verbal and non-verbal cues gives the opportunity to support someone who is considering committing suicide. In this article, I will answer the question whether Jan Komasa's film Sala samobójców adequately presents the problem of suicidal behavior among adolescents.

KEYWORDS: youth, virtual world, thoughts of suicide, suicide, traumatic event 
Na świecie blisko 800 tysięcy osób rocznie ginie w wyniku podjęcia próby samobójczej, co daje ponad 2000 zgonów dziennie1. W Polsce z kolei codziennie odbiera sobie życie ok. 14 osób $^{2}$. Samobójstwo stanowi trzecią najczęstszą przyczynę zgonów w grupie wiekowej 15-19 lat. Wskaźnik poziomu samobójstw jest wyższy w krajach bardzo wysoko oraz wysoko rozwiniętych niż w krajach średnio i słabo rozwiniętych. Pomimo rozwoju nauk społecznych zjawisko zamachu samobójczego wciąż stanowi temat tabu w ogólnym dyskursie. Stereotypowe postrzeganie tego czynu prowadzi do pewnej ambiwalencji wewnętrznej osób, które zostały poinformowane o tym, że inny człowiek planuje popełnić samobójstwo. Pomimo licznych informacji w sferze medialnej dotyczących prób samobójczych (zakończonych zgonem lub nie) osoby trzecie nie podejmują często żadnych kroków, aby udzielić wsparcia jednostce, która planuje odebrać sobie życie. Ponadto bardzo często następuje stygmatyzacja rodziny denata, co utrudnia najbliższym przeżycie żałoby.

W artykule udzielę odpowiedzi na pytanie, czy film Jana Komasy Sala samobójców $\mathrm{w}$ odpowiedni sposób przedstawia problematykę zachowań samobójczych wśród adolescentów. Ponadto opiszę czynniki ryzyka wzmagające zachowania samobójcze głównego bohatera. Dokonam również analizy wpływu otoczenia społecznego na zachowanie nastolatka.

Film jako element kultury masowej dostarcza wiedzy, jest nośnikiem wrażeń, emocji oraz sposobem na przyjemne spędzenie czasu wolnego. Wykorzystanie obrazu filmowego jako narzędzia edukacyjnego stanowi alternatywę dla tradycyjnych metod nauczania. Omawiana produkcja przedstawia m.in. zjawisko uzależnienia od Internetu, cyberprzemoc oraz problematykę zachowań samobójczych.

Niewiele jest polskich produkcji filmowych dotyczących zjawiska samobójstwa, dlatego też pragnę skupić się na filmie w reżyserii i ze scenariuszem Jana Komasy Sala samobójców. Miał on swoją premierę w 2011 r., a w główne role wcielili się Jakub Gierszał (Dominik Santorski), Roma Gąsiorowska (Sylwia), Agata Kulesza (Beata Santorska - matka Dominka) oraz Krzysztof Pieczyński (Andrzej Santorski - ojciec Dominika). Film jest zaliczany do gatunku dramatu psychologicznego.

Produkcja adresowana jest do adolescentów, została przygotowana w sposób przystępny dla młodzieży i dorosłych. Łączy elementy świata rzeczywistego i życia w świecie wirtualnym. Jeszcze dziesięć lat temu, gdy omawiany obraz był obecny na ekranach kin, można było rozdzielić te dwie rzeczywistości, jednak współcześnie staje się to coraz trudniejsze. W obecnych czasach człowiek żyje w obu tych światach jednocześnie.

${ }_{1}^{1}$ https://www.who.int/news-room/fact-sheets/detail/suicide [data dostępu: 20.05.2021].

2 https://statystyka.policja.pl/st/wybrane-statystyki/zamachy-samobojcze [data dostępu: 20.05.2021]. 
Dystrybutor określił, że film jest przeznaczony dla osób, które ukończyły 15. rok życia. Jednak biorąc pod uwagę możliwość zakupienia płyty DVD w sklepie stacjonarnym bądź online, wiek potencjalnego odbiorcy filmu jest trudny do sprawdzenia. Ponadto istnieją liczne formy nielegalnego dostępu do materiałów audiowizualnych. W związku z tym należy stwierdzić, że film ten może obejrzeć praktycznie każdy. Z jednej strony dostęp do materiałów dotyczących zjawiska samobójstwa w dobie powszechnego dostępu do Internetu jest właściwie nieograniczony. Wobec powyższego dzieci i młodzież mogą zdobyć informacje na temat sposobu podjęcia próby samobójczej, zdobycia leków lub środków psychoaktywnych. Z drugiej strony mogą oni także pozyskać wiedzę na temat możliwości uzyskania wsparcia.

Akcja filmu przedstawia losy rodziny Santorskich. Andrzej Santorski jest znanym politykiem, a Beata Santorska kierowniczką dobrze prosperującej firmy zajmującej się PR-em. Ich nastoletni syn Dominik to uczeń prywatnego liceum w Warszawie. Rodzice tylko pozornie interesują się życiem chłopaka. Są zapracowani, rozwijają kariery, umacniają swoją pozycję społeczną. Swą nieobecność w życiu Dominika próbują rekompensować drogimi gadżetami i markowymi ubraniami. Ponadto zatrudniają prywatnego kierowcę i pomoc domową, których zadaniem jest sprawować opiekę nad chłopakiem podczas ich nieobecności. Sam Dominik, wbrew pozorom, nie jest przeciętnym nastolatkiem przygotowującym się do egzaminu maturalnego. Jego życie znacząco odbiega od dnia codziennego rówieśników. Poza tym jest niezwykle roszczeniowy wobec innych osób. Swoim zachowaniem wyraża niezadowolenie z błahych powodów.

Pierwszych negatywnych zmian w zachowaniu bohatera należy szukać podczas balu studniówkowego. Uczniowie znajdujący się pod wpływem alkoholu namawiają się wzajemnie do wykonania określonych zadań, które utrwalają za pomocą telefonów komórkowych. $\mathrm{W}$ pewnym momencie jedna $\mathrm{z}$ osób sugeruje, żeby Dominik pocałował chłopca o imieniu Aleks. Początkowo bohater stanowczo odmawia, jednak po pewnym czasie ulega presji rówieśniczej i wykonuje zadanie. Całe zdarzenie zostaje utrwalone i opublikowane w portalach społecznościowych. Incydent ten staje się początkiem serii negatywnych wydarzeń, które spowodują zmiany w zachowaniu Dominika. Materiał jest oglądany przez znajomych chłopca, pojawiają się pod nim liczne komentarze poniżające bohatera. Nastolatek zaczyna odczuwać wiele trudnych emocji, ponieważ jego czyn stał się obiektem drwin. Zostaje wykluczony z grupy rówieśniczej w środowisku szkolnym. Bohater staje się ofiarą nie tylko cyberprzemocy, ale również przemocy rówieśniczej.

Jakiś czas później, w trakcie sparingu pomiędzy Dominikiem a Aleksem podczas zajęć judo dochodzi do zbliżenia ciał obu chłopców, co wywołuje u Dominika erekcję i ejakulację. Zdarzenie zostaje opisane przez drugiego z chłopców w Internecie i szybko staje się popularne wśród uczniów szkoły. Ze względu na udokumentowane okoliczności główny bohater zostaje posądzony o bycie ho- 
moseksualistą. Z treningu judo ucieka, korzystając z komunikacji miejskiej, gdyż jego prywatny kierowca nie jest w stanie przyjechać o żądanej przez Dominika porze. Następuje zderzenie $\mathrm{z}$ brutalną rzeczywistością - $\mathrm{w}$ trakcie przejazdu dochodzi do bójki, w wyniku której cierpi również maturzysta.

Wszystkie wspomniane sytuacje rozpoczynają proces izolowania się Dominika od innych osób - zamyka się w swoim pokoju, coraz częściej komunikuje się z innymi tylko za pomocą Internetu. Bohater wyznaje w późniejszym czasie rodzicom swoją orientację seksualną, jednak nie spotyka się ze zrozumieniem z ich strony. Właściwie należy uznać, że rodzice zbagatelizowali wyznanie syna i skrytykowali go. Niestety, nastolatek nie uzyskał właściwego wsparcia ani ze strony najbliższych, ani placówki oświatowej.

Zrozpaczony Dominik odreagowuje trudne emocje, korzystając z Internetu. W czasie przeszukiwania Sieci odnajduje transmisję, podczas której młoda dziewczyna dokonuje aktu samookaleczenia. Sytuacja wzbudza zainteresowanie młodego Santorskiego, który próbuje nawiązać kontakt z tajemniczą kobietą. W ten sposób poznaje Sylwię, twórczynię Sali samobójców.

Sala samobójców stanowi zamknięty świat znajdujący się w wirtualnej rzeczywistości nazwanej w filmie Create Yourself - mieści się na wyspie w budynku przypominającym katedrę. Po wejściu do Sali można zauważyć wiele nagrobków należących do słynnych samobójców, takich jak Virginia Woolf czy Yukio Mishima. Wirtualny świat wydaje się mieć nieograniczone możliwości, postaci mogą w nim bowiem latać, tworzyć nowe przedmioty i miejsca. Możliwości te bez wątpienia zachęcają do spędzenia $\mathrm{w}$ tej przestrzeni sporej ilości czasu, albowiem to, co jest niemożliwe i niedostępne w prawdziwej rzeczywistości, jest dostępne na wyciągnięcie ręki w Sali. Dziewczyna wprowadza postać Dominika do wirtualnego świata, poucza go, jakie zasady obowiązują na jego terenie. Główny bohater spędza w Sali coraz więcej czasu.

Opisana sytuacja jest niezwykle podobna do zjawiska hikikomori ${ }^{3}$, biorąc pod uwagę zainteresowanie współczesnej młodzieży kulturą Dalekiego Wscho$\mathrm{du}$ oraz korzystanie $\mathrm{z}$ narzędzi technologii informacyjno-komunikacyjnych nawet kilka godzin każdego dnia. Termin hikikomori wprowadził Tamaki Saitou w 1961 r., opisując zachowanie młodzieży objawiające się wycofaniem się z relacji w świecie rzeczywistym; trwa ono co najmniej sześć miesięcy. Ponadto jednostka przenosi swoje relacje społeczne do rzeczywistości wirtualnej. Utrzymuje kontakty ze światem zewnętrznym jedynie poprzez narzędzia technologii informacyjno-komunikacyjnych, ponieważ tradycyjne metody kontaktów przerażają ją. Następuje zaburzenie cyklu dobowego, jednostka śpi w dzień, a aktywność wykazuje w godzinach nocnych. W związku z tym najczęściej dochodzi do porzucenia nauki czy pracy, natomiast podejmowane aktywności polegają

3 B. Szluz, „Hikikomori” - o syndromie wycofania społecznego młodych ludzi, „Seminare” 2018 , t. 39 , nr 1, s. $81-90$. 
na korzystaniu z dóbr internetowych, takich jak np. oglądanie filmów, granie ${ }^{4}$. Należy zaznaczyć, że owo zjawisko nie stanowi odrębnej jednostki chorobowej, albowiem trudno zakwalifikować je jako chociażby fobię społeczną czy zaburzenia lękowe, ponieważ nie spełnia ono kryteriów diagnostycznych wspomnianych zaburzeń psychicznych. Zachowanie jednostki należy traktować jako wybór, styl życia czy też formę sprzeciwu wobec świata realnego. Pomimo tego, że hikikomori zostało opisane po raz pierwszy w Japonii, występuje w innych krajach Azji, a coraz częściej zaczyna się o nim wspominać także w Europie.

Podobnie przedstawia się zjawisko cocooning (kokonizm), o którym Magdalena Kowalska ${ }^{5}$ pisze, że polega na izolowaniu się od otoczenia i budowaniu własnej przestrzeni. Kokoniarze, zamykając się w swojej prywatnej przestrzeni, zyskują poczucie kontroli nad własnym życiem. Ze względu na prężny rozwój nowoczesnych technologii człowiek ma w zasadzie nieograniczoną możliwość wybierania treści przekazu, samodzielnego tworzenia treści i oferowania ich innym osobom. W tym rozumieniu należy uznać zjawisko hikikomori za patologiczną odmianę kokonizmu. Termin cocooning został wprowadzony w latach 80. XX w. przez Faith Popcorn ${ }^{6}$. Wspomniana autorka wyróżnia trzy odmiany tego zjawiska. Pierwszą stanowi socialized cocooning, polegający na przeniesieniu czynności życia codziennego do własnego domu. Druga to wandering cocooning, dotyczący odcinania się od świata zewnętrznego - osoba taka żyje niejako w kokonie. Przykładem takiego zachowania jest chodzenie w przestrzeni publicznej ze słuchawkami w uszach i słuchanie muzyki, która zagłusza otoczenie. Trzecia odmiana - armored cocooning - łączy się z życiem na osiedlach zamkniętych bądź strzeżonych, zakładaniem kamer, wynajmowaniem ochrony. Jednostka odcina się od świata zewnętrznego, nie pozwala osobie niepowołanej w jej mniemaniu - dostać się do jej przestrzeni.

Wspomniany trend został zaobserwowany na terenie USA i dotyczył przede wszystkim osób pracujących w trybie home office. W dobie pandemii COVID-19 coraz więcej ludzi korzysta $z$ tej metody pracy, co prowadzi do zatarcia granicy pomiędzy wykonywaniem obowiązków zawodowych a odpoczynkiem i życiem prywatnym/domowym. W związku z tym istnieje ryzyko, że wspomniane zjawisko rozpowszechni się również $\mathrm{w}$ innych krajach.

W wirtualnym świecie Dominik spotyka inne osoby, które przejawiają zaburzenia psychiczne. Szczególną uwagę należy poświęcić postaci Sylwii, która już od trzech lat żyje w odosobnieniu. Dziewczyna świetnie manipuluje innymi osobami należącymi do Sali, przejawia zachowania autoagresywne, a ponadto otwarcie wyraża swój ból istnienia i pragnienie śmierci. Namawia także innych graczy do podejmowania zachowań ryzykownych.

4 Ibidem.

5 M. Kowalska, Wpływ wirtualizacji zachowań konsumenckich na rozwój domocentryzmu, „Handel Wewnętrzny” 2015, nr 6, s. 64-73.

6 Ibidem. 
Wygląd zewnętrzny kobiety wydaje się potwierdzać jej wcześniejsze deklaracje dotyczące pozostawania w odosobnieniu. Włosy dziewczyny są zmierzwione, brudne, spięte w kucyk oraz pofarbowane na różowo. Nie są widoczne odrosty wskazujące na ich naturalny kolor. Ubrania Sylwii mają ciemny kolor - najczęściej są to koszulki i spodnie dresowe.

Oprócz Sylwii i Dominika w Sali samobójców znajdują się Jasper, Sirius, Kreska, Regina oraz dwie inne osoby, których pseudonimy nie zostają ujawnione. Jasper dołączył do Sali samobójców znacznie wcześniej niż główny bohater dokonał tego za namową twórczyni Sali, która wyznała, że go kocha. Zwróciła także szczególną uwagę na jego wrażliwość. Postać Jaspera jest agresywna i nieco apodyktyczna. Pomimo tego próbuje on uchronić Dominika przed manipulacją ze strony Sylwii. Cała sytuacja doprowadza do pojedynku pomiędzy bohaterami - wygrywa go Santorski, a Jasper musi opuścić Salę. W ramach odwetu włamuje się na konto administratorki, aby móc ponownie wejść do Sali.

Kolejna postać to Sirius. On również dołączył do Sali przed Dominikiem, a w trakcie włamania Jaspera na konto Sylwii zostaje ujawniona informacja, że jest on osobą z niepełnosprawnością, poruszającą się na wózku inwalidzkim. Sytuacja ta prowadzi do zachwiania równowagi emocjonalnej Siriusa, który staje się agresywny wobec Jaspera.

O pozostałych postaciach niewiele wiadomo, pojawiają się niekiedy w Sali, jednak nie pełnią w niej istotnej funkcji.

Jako pierwsza problem głównego bohatera dostrzega, zatrudniona przez jego rodziców, pomoc domowa. Kobieta zauważa, że chłopak nie opuszcza pokoju, czasami nawet nie zjada przygotowanych przez nią posiłków. Ze względu na prawie ciągłą nieobecność w domu Santorskich decyduje się na wezwanie policji, która wyważa drzwi do pokoju Dominika. Wówczas dochodzi do pierwszej próby samobójczej bohatera. Chłopak tłucze lustro i kawałkami szkła okalecza swoje ciało. Zostaje przewieziony do szpitala psychiatrycznego. Rodzice Dominika nie mieli świadomości powagi sytuacji, a ojciec chłopaka ma pretensje do zatrudnionej kobiety, że nic nie wiedział na temat problemów syna. Rodzice wymuszają na lekarzu psychiatrze możliwość rozmowy z synem, chcą zabrać go z placówki, na co lekarz nie wyraża zgody. Przypomina im obowiązujące procedury oraz fakt, że Dominik jest dorosły. Zwraca uwagę Santorskim, że chłopak ma głęboką depresję, która wymaga leczenia.

Po tym zdarzeniu pomoc domowa zostaje zwolniona, a Dominik wraca do domu. Santorscy we własnym zakresie zatrudniają lekarza psychiatrę - Dariusza, który podejmuje liczne próby nawiązania porozumienia pomiędzy rodzicami a chłopcem. Metody stosowane przez psychiatrę są krytykowane i niedoceniane przez rodziców Dominika. W wyniku kłótni dochodzi do zwolnienia specjalisty. Podczas sprzeczki ojciec uszkadza kable doprowadzające Internet do domu, co powoduje atak paniki Dominika - chłopak krzyczy, płacze, jest agresywny. Po tym incydencie dochodzi do rozmowy pomiędzy członkami rodziny. Syn wy- 
jawia rodzicom, że chce spędzać czas w Sali, ponieważ ludzie, którzy się w niej znajdują, są dla niego jak rodzina, są mu bliscy i są dla niego wsparciem. Po tej konfrontacji rodzice chłopca po raz kolejny decydują się na skorzystanie z pomocy specjalisty. Zatrudniają następnego lekarza psychiatrę - Karolinę, która prowadzi przez drzwi rozmowę z Dominikiem. Lekarka nie ma jednak świadomości, że tak naprawdę rozmawia z chłopcem i z Sylwią, która podpowiada Dominikowi, co ma mówić, aby dostać receptę na leki psychotropowe. Cel zostaje osiągnięty - chłopak ma do nich teraz nieograniczony dostęp.

Sylwia namawia młodego Santorskiego, aby udał się z tabletkami do klubu. Chłopak początkowo poszukuje w budynku dziewczyny, jednak ze względu na jej nieobecność zamawia piwo i zaczepia inne osoby znajdujące się w klubie. Ponieważ Sylwia nie zjawia się w umówionym miejscu, Dominik udaje się do toalety, gdzie początkowo wyrzuca część tabletek, jednak po krótkiej chwili zastanowienia przyjmuje pozostałe i popija je alkoholem. W wyniku podjętych działań i braku pomocy ze strony innych osób, które znajdowały się w klubie, chłopak umiera.

W jaki sposób ukazane jest zjawisko samobójstwa i wizerunek samego samobójcy w omawianym filmie? Przede wszystkim należy zauważyć, że głównym bohaterem jest nastoletni Dominik, co jest zgodne z danymi epidemiologicznymi - wspomniane zjawisko dotyczy najczęściej mężczyzn i osób w młodym wieku. Chłopak jest jedynakiem, pochodzi z zamożnej rodziny, jednak rodzice nie poświęcają mu należytej uwagi. Najwięcej czasu poświęca mu zatrudniona przez rodziców pomoc domowa. Na początku filmu nastolatek uczęszcza do szkoły i nie sprawia znaczących problemów wychowawczych. Dominik jest wysoki i szczupły, ma czarne włosy. Ubiera się najczęściej w ciemne koszulki i ciemne spodnie, ma charakterystyczną fryzurę oraz makijaż, co można wiązać z subkulturą emo.

Subkultura emo pojawiła się po raz pierwszy w latach 80 . XX w. na terenie Stanów Zjednoczonych, stanowiąc sprzeciw wobec materialistycznego oraz agresywnego stylu życia, jaki przejawiali amerykańscy raperzy i inne osoby medialne. Określenie emo pochodzi od angielskiego słowa emotion, które oznacza emocje. Łączy się z odczuwaniem silnych uczuć związanych z egzystencją w określonych warunkach społeczno-kulturowych. Członkowie tej subkultury cechują się zarówno charakterystycznym wyglądem, jak i sposobem zachowania ${ }^{7}$. Do cech tej grupy należy zaliczyć:

- zwykle ciemny strój, najczęściej w kolorze czarnym;

- charakterystyczną fryzurę z grzywką; włosy w kolorze czarnym, różowym, fioletowym lub czerwonym;

7 E. Pietrucha, Emo-cje współczesnej młodzieży. Subkultura emo - przykład zagubienia młodzieży w ponowoczesnym świecie, w: Czy stracone pokolenie? Młodzież i jej dylematy na początku XXI wieku, red. P. Długosz, H. Kotarski, W. Jedynak, Wydawnictwo Uniwersytetu Rzeszowskiego, Rzeszów 2014, s. 143-151. 
- ciemny i ostry makijaz;

- paznokcie pomalowane na ciemny kolor (najczęściej czarny);

- zatarcie granicy między płciami ze względu na podobny sposób ubioru i zbliżone fryzury, tzw. moda unisex;

- zachowania autoagresywne;

- częste refleksje o śmierci;

- wyrażanie swojej emocjonalności poprzez pisanie wierszy i piosenek, tworzenie prac plastycznych, grę na instrumentach itp. ${ }^{8}$.

Nie bez powodu w fabule filmu ukazane są czynniki ryzyka, stanowią one bowiem pewien sygnał ostrzegawczy, a jego zauważenie daje możliwość podjęcia odpowiednich działań. W produkcji uwzględniono następujące czynniki ${ }^{9}$ :

- płeć męska, wiek 15-29 lat;

- trudna sytuacja rodzinna;

- wydarzenia traumatyczne;

- uzależnienia behawioralne;

- depresja.

Jednak w przypadku Dominika większość jego zachowań została zbagatelizowana przez otoczenie. Z fabuły filmu nie można wywnioskować, czy w związku z nieobecnościami Santorskiego w szkole zostały podjęte jakiekolwiek działania. Wątek opublikowania w Internecie kompromitujących Dominika materiałów również nie został rozbudowany. Jednak bez wątpienia należy zaznaczyć, że główny bohater stał się ofiarą cyberprzemocy. Przeżywanie trudnych doświadczeń związanych z zaistniałą sytuacją oraz brak wsparcia ze strony najbliższych nie ułatwiły chłopakowi przezwyciężenia kryzysu. Nastolatek prawdopodobnie nie otrzymał wsparcia placówki edukacyjnej (z fabuły filmu nie wynika, ażeby takie się pojawiło), a rodzice Dominika przez długi czas nie rozumieli wagi problemu. Współpraca Santorskich ze specjalistami w zakresie psychiatrii była utrudniona ze względu na ich silne próby wyparcia problemu. Niezrozumienie płynące z otoczenia spowodowało, że chłopak jeszcze bardziej odizolował się od realnego świata i coraz więcej czasu spędzał w rzeczywistości wirtualnej.

Aby udzielić odpowiedzi na pytanie, czy film Jana Komasy Sala samobójców w odpowiedni sposób przedstawia problematykę zachowań samobójczych wśród adolescentów, pragnę omówić pedagogiczne konteksty kwestii podjętych w produkcji.

Po pierwsze, okres dorastania związany jest z intensywnym poszukiwaniem własnej tożsamości, szukaniem celu i sensu życia. Wiele młodych osób zastana-

8 A. Czyńska, Cierpienia młodego Emo, w: Młodzież w XXI wieku. Źródła wzrostu i kryzysów, red. E. Jackowska, B. Kromolicka, Print Group Daniel Krzanowski, Szczecin 2010, s. 49-60.

9 E. Greszta i in., Uwarunkowania samobójstw - przegląd teorii i badań, „Fides et Ratio” 2018, t. 33, nr 1, s. 263-289; K. Harasim, Generatory zachowań suicydalnych adolescentów - ujęcie analityczne, „Międzynarodowe Studia Społeczno-Humanistyczne HUMANUM” 2017, t. 27, nr 4, s. $117-130$. 
wia się, kim są, czego chcą i dokąd zmierzają. Przeżywanie kryzysu tożsamości wiąże się z doświadczaniem trudnych, a czasem nawet skrajnych stanów emocjonalnych ${ }^{10}$. Nie bez znaczenia w owym czasie jest wsparcie rodziny, którego Dominik właściwie nie doświadcza. Dobrostan materialny, który zapewniają mu rodzice, jest niewystarczający, zważywszy na niezaspokajanie potrzeb emocjonalnych syna. Zaburzone relacje rodzinne i brak akceptacji ze strony najbliższych nie pozostają bez znaczenia, stają się jednym z wielu powodów ucieczki bohatera w świat wirtualny.

Po drugie, praktycznie nieograniczony dostęp do informacji związanych $\mathrm{z}$ tematyką suicydalną. W dobie powszechnego dostępu do Internetu wystarczy wpisać w wyszukiwarkę słowo „samobójstwo”, a już po krótkiej chwili otwierają się setki stron łączących się z tym wyrazem. Oczywiście nie wszystkie wyniki wyszukiwania dotyczą metod odebrania sobie życia, są wśród nich również wpisy dotyczące wsparcia dla osób znajdujących się w kryzysie suicydalnym. Pod tym względem sieć internetowa może być zarówno faktorem ryzyka, jak i chroniącym.

Po trzecie, język stosowany podczas opisywania zjawiska samobójstwa charakteryzuje się specyficznymi sformułowaniami, które nie zawsze są zrozumiałe dla osób niezajmujących się tą tematyką. W związku z tym, nawet jeśli jednostka znajdzie stronę, na której może przeczytać o formach wsparcia, jakie może uzyskać, nie zawsze ma w sobie motywację, żeby z tego skorzystać. Jednak można też spotkać wpisy przedstawiające akt samobójczy jako coś dobrego, jako sposób na uwolnienie się od problemów życia codziennego. Można znaleźć informacje na temat sposobów odebrania sobie życia bez narażania osób bliskich na nieświadome uczestniczenie w tym akcie.

Po czwarte, wirtualne miejsce spotkań. Elementem wyróżniającym jest specyficzne miejsce (Sala samobójców) stworzone ze względu na potrzeby osób przejawiających tendencje suicydalne. Ten wirtualny świat staje się miejscem do dyskusji, umożliwiającym dzielenie się informacjami oraz doświadczanymi emocjami, a ponadto jest miejscem wspierania się w procesie urzeczywistniania podjętej wcześniej decyzji. Osoby spotykające się w Sali stanowią pewną zhierarchizowaną grupę społeczną, $\mathrm{z}$ wewnętrznymi strukturami. W tym miejscu warto przytoczyć klasyfikację Barbary Szackiej ${ }^{11}$, która wyodrębnia struktury: socjometryczną, przywództwa i komunikacji. Przedstawiona w filmie grupa stworzyła pewne relacje, zachodziły w niej procesy, których nie sposób sprowadzić do działań poszczególnych jednostek. Socjometria zajmuje się istniejącymi w grupie oddziaływaniami między jej członkami. Struktura socjometryczna jest afektywna, oparta na uczuciach i emocjach w grupie. Członkami Sali są młodzi

${ }_{10}$ H. Liberska, Specyfika kształtowania się tożsamości współczesnej młodzieży, w: Z zagadnień psychologii rozwoju człowieka, red. E. Rydz, D. Musiał, Towarzystwo Naukowe Katolickiego Uniwersytetu Lubelskiego Jana Pawła II, Lublin 2007, s. 143-158.

11 B. Szacka, Wprowadzenie do socjologii, Oficyna Naukowa, Warszawa 2008. 
ludzie odrzuceni przez swoje najbliższe otoczenie. Spotykają się ze sobą, poszukując wzajemnego wsparcia. Zbierają informacje na temat środków niezbędnych do popełnienia samobójstwa. Z kolei struktura przywództwa opisuje zależności w zakresie sprawowania i podlegania władzy. Niewątpliwie w filmie osobą sprawującą władzę jest Sylwia i robi to w sposób apodyktyczny. Osoby, które sprzeciwiały się dziewczynie, zostały usunięte z Sali, bez możliwości powrotu. Ponadto w Sali obowiązują pewne wzory zachowań i reguły postępowania uznawane i przestrzegane przez jej członków. W strukturze komunikacji analizie podlegają modele komunikacji oraz ich wpływ na sposób funkcjonowania grupy jako całości. Każdy członek Sali może komunikować się z pozostałymi osobami. Nie można wyróżnić konkretnego modelu komunikacji ani określić jego wpływu na funkcjonowanie grupy. Język stosowany w grupie jest zróżnicowany. W wypowiedziach pojawia się slang młodzieżowy dotyczący czynności życia codziennego, a ponadto specyficzne określenia związane z zachowaniami suicydalnymi. Zjawisk zachodzących w Sali nie jest w stanie zaobserwować osoba spoza niej. Główny bohater w trakcie rozmowy z rodzicami oznajmia, że członkowie grupy są dla niego jak rodzina, czego Santorscy nie są w stanie zrozumieć.

Po piąte, przygotowywanie się do własnej śmierci. Dotyczy to przede wszystkim fantazjowania o własnej śmierci, zbierania środków, które umożliwią popełnienie samobójstwa. Chodzi tu też o sprawdzanie, po jakim czasie od zażycia niewielkiej ilości substancji toksycznej pojawiają się działania niepożądane.

Po szóste, zespół abstynencyjny i współuzależnienie. Obserwując scenę, podczas której ojciec Dominika wyrywa kable sieciowe, warto zwrócić uwagę na zachowanie poszczególnych członków rodziny. Chłopak wpada w szał, jest agresywny, błaga o ponowne podłączenie Internetu. Matka wykazuje cechy współuzależnienia - widząc zachowanie syna, próbuje podłączyć przewody. Rodzice Dominika uświadamiają sobie, że ich syn ma poważny problem, jednak kompletnie nie wiedzą, co powinni zrobić. W obliczu trudności i niemożności poradzenia sobie z całą sytuacją Santorscy nie przyjmują pomocy z zewnątrz, ukrywają przed sobą oraz otoczeniem problem.

Po siódme, niewystarczająca pomoc psychologiczna. Na przykładzie Dominika należy zauważyć, że sama pojedyncza wizyta u psychiatry czy psychologa jest często niewystarczająca. Ponadto często najbliższe otoczenie osoby z tendencjami suicydalnymi nie jest w stanie zrozumieć potrzeby leczenia czy też odbycia terapii. Wspieranie osoby, która przejawia zachowania samobójcze, to proces - niejednokrotnie długotrwały i wymagający poświęcenia znacznej ilości czasu - który nie przynosi natychmiastowych efektów.

Warto jednak mieć świadomość, że opisane aspekty nie występują (bądź występują częściowo) zawsze i w każdej rodzinie, w której dochodzi do samobójstwa jednego z jej członków. Film Sala samobójców podejmuje wiele istotnych tematów z punktu widzenia zarówno młodych ludzi, jak i ich rodziców. Przed- 
stawia obraz polskiej rodziny, w której niezależnie od statusu socjoekonomicznego występują różne trudności. Mogą one dotyczyć kwestii cyberprzemocy, zaburzeń więzi rodzinnych, zjawiska uzależnienia, ukrywania problemów rodzinnych przed światem zewnętrznym. Produkcja właściwie prezentuje problematykę zachowań samobójczych wśród adolescentów. W sposób przystępny dla młodzieży, rodziców i innych osób pracujących z dorastającymi ludźmi ukazuje dramat młodego człowieka borykającego się z licznymi trudnościami, których nie jest w stanie samodzielnie przezwyciężyć.

Film spotkał się zarówno z przychylnymi, jak i nieprzychylnymi ocenami. $\mathrm{Z}$ jednej strony doceniono, że ukazuje problematykę zachowań suicydalnych wśród młodzieży, z drugiej jednak pojawił się kontrargument stwierdzający, że fabuła została przerysowana oraz że ukazuje zjawisko w sposób stereotypowy. Zarzut ten wydaje się nietrafiony. Przedstawiony w filmie obraz zjawiska samobójstwa jest zgodny z literaturą przedmiotu, a ponadto nie piętnuje rodzin, w których pojawia się problem zachowań suicydalnych.

Z historycznego punktu widzenia zdrowie psychiczne było mniej uprzywilejowane i długo nie traktowano go priorytetowo. Sytuacja współcześnie bardzo się zmieniła, ale jednak pomimo rozwoju nauk o zdrowiu psychicznym człowieka problem dostępu do specjalistów z tej dziedziny wciąż jest aktualny.

Poczyniona analiza wpisuje się w szerszy kontekst rozważań nad problematyką zachowań suicydalnych wśród adolescentów. Od premiery filmu minęła dekada - warto zastanowić się, czy w zakresie percepcji zjawiska samobójstwa wśród młodzieży nastąpiły zmiany.

\section{Bibliografia}

Brol M., Skorupa A., Psychologiczna praca $z$ filmem, Wydawnictwo Uniwersytetu Śląskiego, Katowice 2014.

Czyńska A., Cierpienia młodego Emo, w: Młodzież w XXI wieku. Źródła wzrostu i kryzysów, red. E. Jackowska, B. Kromolicka, Print Group Daniel Krzanowski, Szczecin 2010, s. 49-60.

Greszta E. i in., Uwarunkowania samobójstw - przegląd teorii i badań, „Fides et Ratio” 2018, t. 33, nr 1, s. 263-289.

Harasim K., Generatory zachowań suicydalnych adolescentów - ujęcie analityczne, „Międzynarodowe Studia Społeczno-Humanistyczne HUMANUM” 2017, t. 27, nr 4, s. 117-130.

https://statystyka.policja.pl/st/wybrane-statystyki/zamachy-samobojcze [data dostępu: 20.05.2021].

https://www.who.int/news-room/fact-sheets/detail/suicide [data dostępu: 20.05.2021].

Kowalska M., Wpływ wirtualizacji zachowań konsumenckich na rozwój domocentryzmu, „Handel Wewnętrzny” 2015, nr 6, s. 64-73. 
Liberska H., Specyfika kształtowania się tożsamości współczesnej młodzieży, w: Z zagadnień psychologii rozwoju człowieka, red. E. Rydz, D. Musiał, Towarzystwo Naukowe Katolickiego Uniwersytetu Lubelskiego Jana Pawła II, Lublin 2007, s. 143-158.

Pietrucha E., Emo-cje współczesnej młodzieży. Subkultura emo - przykład zagubienia młodzieży w ponowoczesnym świecie, w: Czy stracone pokolenie? Młodzież i jej $d y$ lematy na początku XXI wieku, red. P. Długosz, H. Kotarski, W. Jedynak, Wydawnictwo Uniwersytetu Rzeszowskiego, Rzeszów 2014, s. 143-151.

Szacka B., Wprowadzenie do socjologii, Oficyna Naukowa, Warszawa 2008.

Szluz B., "Hikikomori” - o syndromie wycofania społecznego młodych ludzi, "Seminare” 2018, t. 39, nr 1, s. 81-90.

\section{mgr ALICJA MAGDALENA PAWLIKOWSKA \\ e-mail: alicjamagdalenapawlikowska@gmail.com}

Uzyskała tytuł magistra z zakresu pedagogiki na Uniwersytecie Mikołaja Kopernika. Obecnie jest nauczycielką w Przedszkolu im. Marii Montessori w Toruniu.

She has obtained a master's degree in pedagogy at the Nicolaus Copernicus University. Currently, she is a teacher at the Maria Montessori Kindergarten in Torun. 